サビ止め効果は軟鋼ではサビ面積試験と重量試験の結 果は同一傾向を示し, ジアリール誘導体間では $p-ク レ$ ゾール誘導体>oークレゾール誘導体>O-第三ブチルフェ ノール誘導体>mークレゾール誘導体, フェノール誘導 体の順に弱くなった。とくに p-クレジール， oークレゾ 一ル誘導体の $0.8 \%$ 添加ではサビ面積 0 , 重量変化な しの好結果を得た。R-7〜R-9 間では 11-オキシカルボ キシフェニル-9-ウンデセン酸塩 $>11$-ジカルボキシフェ ニル-9-ウンデセン酸塩>11-カルボキシフェニル - $9-$ ウ ンデセン酸塩の順であった。金属塩類間ではストロンチ ウム塩, バリウム塩が同程度に良く, ついでカルシウム 塩で，この 3 者の $0.8 \%$ 溶液を用いた場合はまったくサ ビが発生しなかった。ナトリウム塩は上記 3 者よりもわ ずかに劣る。アルミニウム, 真チュウではアリール基に よる差は小さいがいずれもサビ止め効果を示し，0.6\% 以上の濃度ではその効果はほぼ一定となった。誘導体間 の差は軟鋼の場合と類似していた。亜鉛では $p$-クレゾ
ール， ーークレゾール誘導体が良好で，前者は $0.8 \%$ で重 量変化なく, 後者では $0.2 \%$ り良好な効果を示した。

終りに御べん達をいただいた茂木今朝吉博士に深謝します。 (昭和 41 年 10 月油化学研究発表会（大阪）で 1 部を，） 昭和 43 年 10 月油化学研究発表会で 1 部を発表した。)

(昭和 43 年 1 月 12 日受理)

\section{文献}

1) E.T. Roe, W.E. Parker, D. Swern, J. Am. Oil Chemists'Soc., 36, 656 (1959) など

2) A. Eisner, T. Perlstein, W.C. Ault, J. Am. Oil Chemists'Soc., 40, 594 (1963) など

3) J. Messina, J. Snead, Ind. Eng. Chem., 48, 2001 (1956) など

4) 御園生, 油化学, 7, 539 (1959) など

5) K. Ichikawa, K. Fujita, O. Itoh, J. Am. Chem. Soc., 84, 2632 (1962) など

6) L.J. Rubin, W. Paisley, J. Am. Oil Chemists' Soc., 37, 300 (1960)

7) 熊沢, 油化学, 8, 405 (1959)

8) 佐藤, 油化学, 4, 14, 184 (1955); 佐藤, 加藤, 工化, 61, 69 (1958)

\title{
鉄を主体とする混合金属酸化物触媒による 高級アルコールの製造研究
}

\author{
池田功・森岡 聡・小森三 郎 \\ 大阪大学工学部応用化学教室 (大阪市都島区東野田 9 )
}

\section{Hydrogenolysis of Higher Fatty Ester to Higher \\ Alcohol using Fe-based Catalyst}

Isao IKedA, Satoshi Morioka and Saburō KomorI

Dept. of Chem. Tech., Faculty of Eng., Osaka Univ. (Higashinoda-9, Miyakojima-ku, Osaka)

The authers previously reported that $\mathrm{Fe}-\mathrm{Cu}-\mathrm{O}$ catalyst had high activity to catalytic hydrogenolysis of higher fatty ester to higher alcohol. After that, it was found that $\mathrm{Fe}-\mathrm{Cu}-\mathrm{Al}-\mathrm{O}$ catalyst had higher activity when proper amount of $\mathrm{Al}$ was contained as third component.

Hydrogenolysis of methyl ricinoleate to 1,12-octadecanediol was studied using the catalyst. The yield was $77 \%$. But when triglyceride was used as raw material, the yield was $50 \%$.

Preparation of unsaturated higher alcohol using $\mathrm{Fe}-\mathrm{Cu}-\mathrm{Cd}-\mathrm{O}$, which was prepared newly, was studied, but $65 \%$ of unsaturation on the product vanished when $93 \%$ of the ester was hydrogenolzyed.

From the study of $\mathrm{X}$-ray defraction on these catalysts before and after the reduction, it was recognized that, as to $\mathrm{Fe}, \mathrm{Fe}_{3} \mathrm{O}_{4}$ was of active from in the reduction.

\section{1 緒言}

高級脂肪酸エステルの接触水素化分解により飽和高級 アルコールを得る反応において，鉄-銅酸化物系触媒が すぐれた活性を示すことはすでに著者らが 報告しだ1)。 この触媒はヤシ油の水素化分解に現在広く使用されてい る銅ークロム酸化物系触媒に比較して，工業化に当って
つぎの点ですぐれたものである。すなわち 1) 鉄が主体 であり，安価である。2) 比較的低温においても活性が 高く，少ない使用量でも高収率でアルコールを得ること ができる。3)クロムのような毒性の強い物質を含まな い。4）触媒の調製法が比較的簡単である。そこで本報 告では，鉄-銅酸化物がこのように高級脂肪酸エステル の接触水素化分解に预ける有望な触媒であることから， 
さらに検討を加えた結果, 第 3 成分としてアルミニウム を適当量添加した場合, 本混合酸化物触媒の活性吕さら に向上することを認めた。また本触媒を用いてリシノー ル酸エステルから 1,12-オクタデカンジオールの製造に ついて検討した。

さらに第 3 成分としてカドミウムを添加した場合の不 飽和結合に対する効果についても検討した。

最後にこれらの触媒がごの程度の酸化状態で活性を示 すかを知る目的で反応前後の状態を粉末 $\mathrm{X}$ 線回折によ り検討した。

\section{2 実験}

\section{$2 \cdot 1 \mathrm{Fe}-\mathrm{Cu}-\mathrm{Al}-\mathrm{O}$ 触媒の検討}

$2 \cdot 1 \cdot 1$ 触媒の調製

市販試薬特級の硝酸第二鉄, 硝酸アルミニウムおよび 硝酸銅を前報 ${ }^{1}$ と同様の処理により混合酸化物とし $\mathrm{Fe}$ $\mathrm{Cu}-\mathrm{Al}-\mathrm{O}$ 触媒とした。な打前報の結果から 鉄対銅の混 合割合をその最適比と考えられる $1 / 2 \mathrm{Fe}_{2} \mathrm{O}_{3}: \mathrm{CuO}=100$ : 20 に一定とした。調製した触媒の金属混合比を Table-1 に示した。

Table-1 Composition of catalyst.

\begin{tabular}{|c|c|c|}
\hline Cat. No. & $\begin{array}{l}\text { Ratio of component } \\
1 / 2 \mathrm{Fe}_{2} \mathrm{O}_{3}: \mathrm{CuO}: 1 / 2 \mathrm{Al}_{2} \mathrm{O}_{3}\end{array}$ & $\begin{array}{l}\text { Yield of mixed } \\
\text { metal oxide }(\%)\end{array}$ \\
\hline 1 & $100: 20: 500$ & 94.2 \\
\hline 2 & $100: 20: 200$ & 94.8 \\
\hline 3 & $100: 20: 100$ & 92.9 \\
\hline 4 & $100: 20: 50$ & 92.3 \\
\hline $4^{\prime * 2}$ & $100: 20: 50$ & - \\
\hline 7 & $100: 20: 15$ & 93.3 \\
\hline $5^{* 8}$ & $100: 20: 5$ & - \\
\hline $6 * 3$ & $100: 20:$ & - \\
\hline
\end{tabular}

*1 Values based on nitrate before mixing.

*2 Partially reduced Cat. 4 , in $\mathrm{H}_{2}$ stream at $300^{\circ} \mathrm{C}$ for $3 \mathrm{hr}$.

*3 Previously reported catalyst $^{11}$.

$2 \cdot 1.2$ 原 料

市販パルミチン酸メチルを蒸留精製し，GLPC で純 数と認められたものを使用した（カラム：Thermol-3， $2.5 \mathrm{~m}, 250^{\circ} \mathrm{C}$ )。ケン化価 207.0 。

$2 \cdot 1 \cdot 3$ 還元反応

前報1と同様の操作で行なった。

$2 \cdot 1 \cdot 4$ 実験結果打よび考察

パルミチン酸メチルの水素化分解結果を Table-2 に 示した。

反応温度とエステル消費量との関係を前報1) の結果と 合わせて Fig.-1 亿示した。

この図から明らかなように $\mathrm{Fe}-\mathrm{Cu}-\mathrm{O}$ に対し $\mathrm{Al}$ を添 加することによって炭化水素の生成温度が引き上げられ ることが判明した。つぎにアルミニウムの添加量とアル
Table-2 Hydrogenolysis of methyl palmitate using $\mathrm{Fe}-\mathrm{Cu}-\mathrm{Al}-\mathrm{O}$ catalyst.

\begin{tabular}{|c|c|c|c|c|c|}
\hline Run & Cat. & $\begin{array}{r}\text { Reaction } \\
\text { temp. }\left({ }^{\circ} \mathrm{C}\right)\end{array}$ & S.V. & $\begin{array}{l}\text { Consumption } \\
\text { of ester }(\%)\end{array}$ & $\begin{array}{l}\text { Hydrocar- } \\
\text { bon (\%) }\end{array}$ \\
\hline 13 & No. 1 & 200 & 192.3 & 7.4 & trace \\
\hline 17 & " & 220 & 164.7 & 21.3 & '" \\
\hline 1 & " & 240 & 35.8 & 83.4 & " \\
\hline 5 & " & 260 & 2.0 & 99.1 & " \\
\hline 9 & " & 280 & 0 & 100 & $<10$ \\
\hline 14 & No. 2 & 200 & 184.0 & 11.6 & trace \\
\hline 18 & " & 220 & 93.0 & 56.4 & " \\
\hline 2 & " & 240 & 1.3 & 99.4 & " \\
\hline 6 & " & 260 & 0 & 100 & $<1$ \\
\hline 15 & No. 3 & 200 & 174.8 & 16.3 & trace \\
\hline 19 & " & 220 & 74.9 & 65.0 & " \\
\hline 3 & " & 240 & 3.3 & 98.4 & " \\
\hline 7 & " & 260 & 0 & 100 & $<3$ \\
\hline 16 & No. 4 & 200 & 153.1 & 27.1 & trace \\
\hline 20 & " & 220 & 16.1 & 92.6 & " \\
\hline 4 & " & 240 & 2.5 & 98.9 & " \\
\hline 8 & " & 260 & 0 & 100 & $<3$ \\
\hline
\end{tabular}

Condition : Raw ester : $4.0 \mathrm{~g}$, Cat. : $0.4 \mathrm{~g}$, Reaction time : $2 \mathrm{hr}$, Initial $\mathrm{H}_{2}$ press. : $200 \mathrm{~kg} / \mathrm{cm}^{2}$

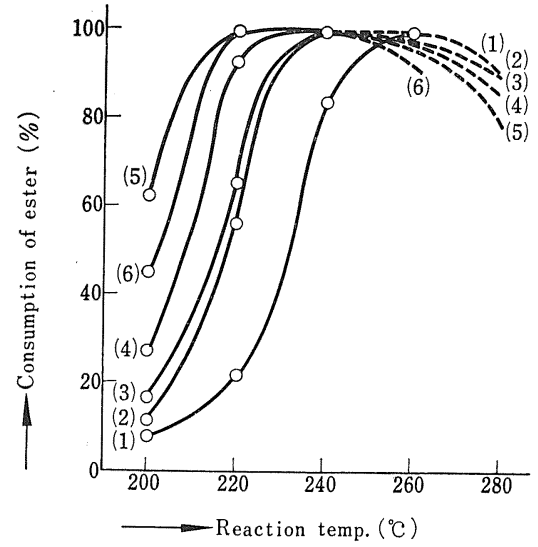

Dotted lines represent the yields of alcohol estimating hydrocarbon generated.

Fig.-1 Consumption of ester vs reaction temperature.

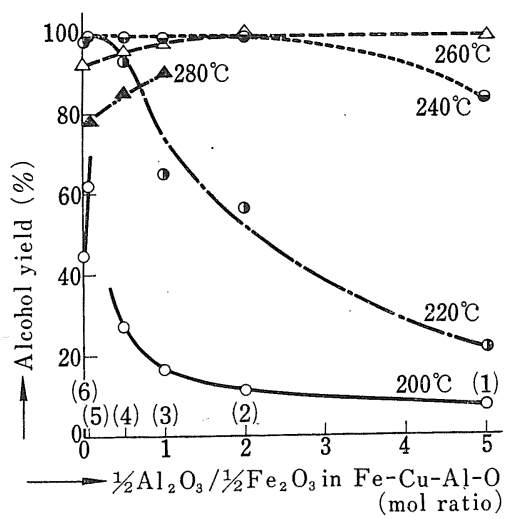

Fig.-2 Alcohol yield vs Al-content. 
コール収率の関係は Fig.-2 に示したとおりである。

Fig.-2 から， $220^{\circ} \mathrm{C}$ 以上の温度ではその差は明らか でないが $200^{\circ} \mathrm{C}$ でみられるよらに,アルミニウムのある 添加割合のときにアルコール収率は最高值を示してい る。そこで Fig.-3 に Fe-Cu-Al-O 中の $\mathrm{Fe}-\mathrm{Cu}-\mathrm{O}$ 量 が一定になるように触媒量を変えたときのアルミニウム 量による収率変化を, 少ない触媒使用量で調べ, 示した。

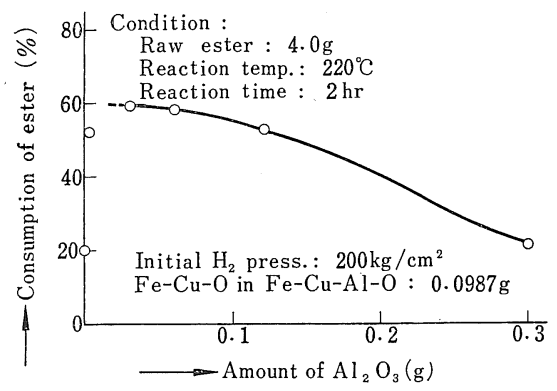

Fig.-3 Alcohol yield vs $\mathrm{Al}-\mathrm{O}$ amount in $\mathrm{Fe}-$ $\mathrm{Cu}-\mathrm{Al}-\mathrm{O}$ containing same amount of $\mathrm{Fe}-\mathrm{Cu}-\mathrm{O}$.

Fig.-3 の結果より $\mathrm{Fe}-\mathrm{Cu}-\mathrm{O}$ に対し約 15\% 程度の $\mathrm{Al}-\mathrm{O}$ (Fe 100 グラム原子に対し Al 11 グラム原子) が含まれるとき最高活性を示すと推定されるので触媒 7 を調製し, 触媒の全体量を $2 \%$ とした場合の結果を Fig. -4 に示した。

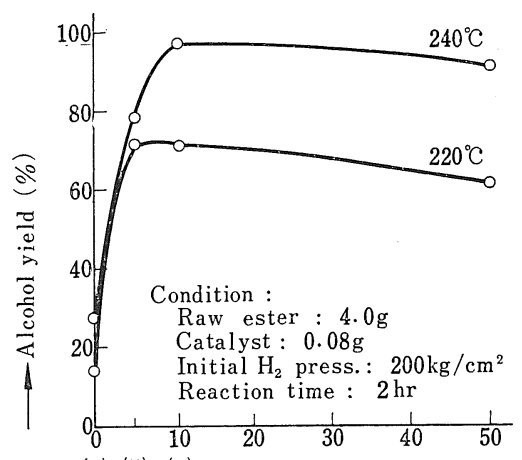

(6) (5) (7)

$\longrightarrow$ Al g-atom vs $100 \mathrm{~g}$-atom of $\mathrm{Fe}$ in $\mathrm{Fe}-\mathrm{Cu}-\mathrm{Al}-\mathrm{O}$

Fig.-4 Alcohol yield vs $\mathrm{Al}$ content in $\mathrm{Fe}-\mathrm{Cu}-\mathrm{Al}-\mathrm{O}$.

この結果からも明らかなよらに本 $\mathrm{Fe}-\mathrm{Cu}-\mathrm{Al}-\mathrm{O}$ 触媒 は $\mathrm{Fe}: \mathrm{Cu}: \mathrm{Al}=100: 20: 11$ (グラム原子)の混合比付 近で最も高い活性を示すことが認められた。

2.2 Fe-Cu-A1-O 触媒による 1,12-オクタデカンジ オールの製造

$2 \cdot 2 \cdot 1$ 触 媒

$2 \cdot 1$ の触媒のらち最も活性の高い触媒 7 を用いた。 $2 \cdot 2 \cdot 2$ 原 料

$2 \cdot 2 \cdot 2 \cdot 1$ リシノール酸メチル 市販ヒマシ油を常
法によりアルカリ触媒存在下にエステル交換してメチル 化し，蔒留精製を行なって GLPC（カラム：Thermol$\left.3,2.5 \mathrm{~m}, 250^{\circ} \mathrm{C}\right)$ で単一ピークを示したものを用い た。bp 190 $1^{\circ} \mathrm{C}$ ，ケン化価 179.0 ，水酸基価 178.5 。

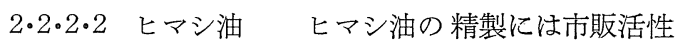
白土を $120 \sim 150^{\circ} \mathrm{C}$ に $1 \mathrm{hr}$ 保持して乾燥したのち使用 した。これを市販ヒマシ油に対し $5 \mathrm{wt} \%$ 加えて， $120^{\circ} \mathrm{C}$ で $1 \mathrm{hr}$ かきまぜたのち，自然口過により白土を 除き試料とした。ケン化価 181.8，水酸基価 160.7 。

$2 \cdot 2 \cdot 3$ 還元反応

$2 \cdot 1 \cdot 3$ と同様の操作により行なった。

$2 \cdot 2 \cdot 4$ 1,12-オクタデカンジオールの定量および計算 式

水素化分解生成物について，ケン化価，水酸基価およ び GLPC によってステアリルアルコール含有量を測定 した。ガスクロマトグラム作成に当たって還元生成物の ままでは分離不充分のうえピークもゆがんだものとなる ため, 遊離の水酸基をトリメチルシリルエーテル化 ${ }^{2)}$ し て行なった。内部標準としてセチルアルコールシリル化 物を用いた。すなわち精ヒョウした生成物とセチルアル コールの混合物をピリジンに溶解し，これにトリメチル クロルシランを加えて室温に放置したのち, 水洗して多 量のピリジンの除去およびトリメチルクロルシランのジ シロキサン化を行なって GLPC 用試料とした。その一 例を Fig.-5 に示した。

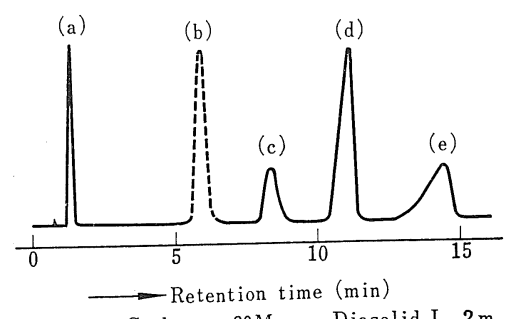

Column : Carbowax 20M on Diasolid L, $2 \mathrm{~m}$ $240^{\circ} \mathrm{C}, \mathrm{H}_{2}$ gas carrier : $60 \mathrm{ml} / \mathrm{min}$

a) Hexamethyl disiloxane

b) Sililated cetyl alcohol (internal standard)

c) Sililated stearyl alcohol

d) Sililated 1,12-octadecane-diol

e) Sililated methyl ricinole,ate (and/or methyl oxystearate)

Fig.-5 GLPC of trimethylsylilated alcohol from hydrogenolyzed methyl ricinoleate.

1,12-オクタデカンジオールの定量はケン化価から求 めたエステル転化率と，GLPC から求めたステアリル アルコール含有量との差として求めた。ここで求めた GLPC 条件では不飽和結合による分離を行なえず，ま た前報 ${ }^{1}$ から本反応が水素化分解速度よりも水素添加速 度の方が大と考えられることから，不飽和度については まったく考慮しなかった。

計算はつぎのとおりである。 $c=[$ ステアリルアルコール $] \mathrm{wt} \%$ 


$$
\begin{aligned}
& C=[\text { ステアリルアルコール }] \text { エステル換算量 } \\
& =c \times \frac{\text { リシノール酸メチル分子量 }}{\text { ステアリルアルコール分子量 }}=1.155 c \\
& B=[\text { リシノール酸メチル }] \text { エステル換算量 } \\
& =b=[\text { リシノール酸メチル }] \mathrm{wt} \% \\
& =\frac{\text { 生成物ケン化価 }}{\text { 原料ケン化価 }} \times 100 \\
& a=[シ ゙ オ ー ル] \mathrm{wt} \%=100-(b+c) \\
& A=[シ ゙ オ ー ル] \text { エステル換算量 } \\
& =a \times \frac{\text { リシノール酸メチル分子量 }}{1,12 \text {-オクタデカンジオール分子量 }} \\
& =1.10 a
\end{aligned}
$$

したがって

$$
\begin{aligned}
& \text { [ジオール }] \operatorname{mol} \%=\frac{A}{A+B+C} \times 100 \\
& \text { [ステアリルアルコール }] \mathrm{mol} \%=\frac{C}{A+B+C} \times 100
\end{aligned}
$$

[未反応リシノール酸メチル] $\mathrm{mol} \%=100-(A+C)$ なお本実験条件下では炭化水素およびステアリン酸メチ ルの生成は GLPC から認められず, 定量に当たっては これらは考慮しなかった。

\section{$2 \cdot 2 \cdot 5$ 実験結果および考察}

$2 \cdot 2 \cdot 5 \cdot 1$ リシノール酸メチルの水素化分解 $2 \cdot 2 \cdot 2 \cdot 1$ で得た原料の水素化分解結果を Table-3 以下 に示した。7〜10\% の触媒使用量のときジオールの収率 はほぼ最高に達したたと思われる值を示し，このとき， 第二水酸基の水素化分解によるステアリルアルコールが

Table-3 Hydrogenolysis of methyl ricinoleate influence of catalyst amount.

\begin{tabular}{r|c|r|r|r|r|r}
\hline \multirow{2}{*}{ Run } & \multirow{2}{*}{$\begin{array}{c}\text { Cat. } \\
\text { (wount }\end{array}$} & \multicolumn{5}{|c}{ Product } \\
\cline { 3 - 7 } & \multicolumn{1}{|c|}{ S.V. } & OH.V. & Diol*1 & StOH $^{* 2}$ & Ester*3 \\
\hline 76 & 2 & 104.4 & 209.3 & 35.6 & 8.1 & 56.3 \\
93 & 5 & 16.5 & 275.0 & 74.2 & 17.4 & 8.4 \\
92 & 7 & 7.6 & 314.4 & 76.8 & 19.4 & 3.8 \\
88 & 10 & 2.6 & 357.0 & 77.0 & 21.7 & 1.3 \\
\hline
\end{tabular}

Reactions were carried out at $240^{\circ} \mathrm{C}$ for $2 \mathrm{hr}$.

*1 1,2-Octadecane diol (mol\%)

*2 Stearyl alcohol (mol\%)

*3 Raw methyl ricinoleate (mol\%)

Table-4 Hydrogenolysis of methyl ricinoleate influence of reaction time.

\begin{tabular}{c|c|c|r|r|r|r|r}
\hline \multirow{2}{*}{ Run } & \multicolumn{2}{|c|}{$\begin{array}{c}\text { Reaction } \\
\text { condition*4 }\end{array}$} & \multicolumn{5}{|c}{ Product } \\
\cline { 4 - 7 } & $\begin{array}{c}\text { Time } \\
\text { (hr) }\end{array}$ & $\begin{array}{c}\text { Temp. } \\
\left({ }^{\circ} \mathrm{C}\right)\end{array}$ & S.V. & OH.V. & Diol*1 & StOH*2 & Ester*3 \\
\hline 96 & $1 / 4$ & 240 & 90.8 & 224.7 & 40.9 & 8.4 & 50.7 \\
94 & $1 / 2$ & $\prime \prime$ & 58.2 & 253.6 & 54.9 & 12.6 & 32.5 \\
95 & 1 & $\prime \prime$ & 15.6 & 311.9 & 70.6 & 20.7 & 8.7 \\
88 & 2 & $\prime \prime$ & 2.3 & 357.0 & 77.0 & 21.7 & 1.3 \\
89 & 2 & 230 & 26.3 & 312.6 & 65.7 & 19.6 & 14.7 \\
90 & 3 & $\prime \prime$ & 3.4 & 332.7 & 76.7 & 21.4 & 1.9 \\
91 & 2 & 220 & 65.5 & 248.3 & 49.5 & 13.9 & 36.6 \\
87 & 3 & $\prime \prime$ & 43.0 & 286.2 & 60.4 & 15.6 & 24.0 \\
\hline
\end{tabular}

$* 1, * 2, * 3$ Same as in Table-3.

$* 4$ Catalyst amount : $10 \mathrm{wt} \%$.
約 $22 \%$ 生成した。

反応時間の影響について Table-4 にその結果を示し た。エステル基と第二水酸基の水素化分解は並列反応で あり，反応の進行とともにステアリルアルコールが生成 することは避けられないことであるが，本実験条件下で は No.88, 90 に示すように 77\% の収率でジオールを 得ることができた。反応温度および時間を変化させても 得られた結果は同様で約 $22 \%$ のステアリルアルコール が副生した。なお $240^{\circ} \mathrm{C}$ を越えると炭化水索の生成が 考えられるので検討しなかった。

$2 \cdot 2 \cdot 5 \cdot 2$ ヒマシ油の水素化分解 $2 \cdot 2 \cdot 2 \cdot 2$ で得た ヒマシ油の水素化分解結果を Table-5 に示した。な お,リシノール酸メチルの場合に用いた収率計算式をそ のまま, 混合脂肪酸から成るグリセリドに適用すること は大きな誤差を生ずる危険性があるが，原料のケン化 価, および水酸基価から，かなり高純度のリシノ一ル酸 から成っているものと考えられるので, ジオールなどの 収率の概算值として算出した。その結果メチルエステル の場合最適と考えられた条件下では約 $50 \%$ しかジオー ルを得ることはできなかった。これはグリセリドとメチ ルエステルの構造的な差によるものか, 粘度の差あるい は精製処理が充分でなかったためかは不明であるが，接 触反応により 1,12-オクタデカンジオールを得るために はまずメチルエステル化の段階を経ることが望ましいと 考えられる。

Table-5 Hydrogenolysis of caster oil.

\begin{tabular}{c|c|c|c|c|c|c|c}
\hline \multirow{2}{*}{ Run } & $\begin{array}{c}\text { Reaction } \\
\text { condition*4 }\end{array}$ & \multicolumn{5}{|c}{ Product } \\
\cline { 2 - 7 } & $\begin{array}{c}\text { Time } \\
\text { (hr) }\end{array}$ & $\begin{array}{c}\text { Temp. } \\
\left({ }^{\circ} \mathrm{C}\right)\end{array}$ & S.V. & OH.V. & Diol $^{* 1}$ & StOH $^{* 2}$ & Ester* \\
\hline 97 & 2 & 240 & 66.5 & 236.8 & 50 & 16 & 34 \\
98 & 3 & 230 & 89.2 & 168.7 & 47 & 6 & 47 \\
\hline
\end{tabular}

$* 1, * 2, * 3, * 4$ Same as in Table-7.

以上 $\mathrm{Fe}-\mathrm{Cu}-\mathrm{Al}-\mathrm{O}$ 触媒 (100:20:11) (グラム原子) を使用することにより約 $22 \%$ の第二水酸基の水素化分 解を伴うが，リシノール酸メチルにより $77 \%$ の収率で 1,12-オクタデカンジオールを得ることができた。

\section{$2 \cdot 3 \mathrm{Fe}-\mathrm{Cu}-\mathrm{Cd}-\mathrm{O}$ 触媒の検討}

\section{$2 \cdot 3 \cdot 1$ 触媒の調製}

$2 \cdot 1 \cdot 1$ と同様の操作により $\mathrm{Fe}-\mathrm{Cu}-\mathrm{Cd}-\mathrm{O}$ を調製した 場合，とくにカドミウム添加量が多いときに金属酸化物 の収率が低くなっており， $\mathrm{Cd}(\mathrm{OH})_{2}$ がアンモニウム塩 の溶液に可溶なため充分沈殿しないと推測されたので, つぎの二種の方法により調製した。

a) $\mathrm{Fe}(\mathrm{OH})_{3}-\mathrm{Cu}(\mathrm{OH})_{2}$ 混合物を 2.1.1 の方法で共 沈させ, $\mathrm{Cd}(\mathrm{OH})_{2}$ を別に硝酸塩から $1 / 10 N-\mathrm{NaOH}$ 水 溶液で沈殿させ，それぞれ遠心分離により脱水し，ふた たびスラリーにもどして，ビブロミキサーで $3 \mathrm{hr}$ 混合 し, 以下 $2 \cdot 1 \cdot 1$ と同様の処理により混合金属酸化物と 
した。

b) $\mathrm{Fe}(\mathrm{OH})_{3}-\mathrm{Cu}(\mathrm{OH})_{2}-\mathrm{Cd}(\mathrm{OH})_{2}$ をとれぞれの硝酸 塩から $1 / 10 N-\mathrm{NaOH}$ により共沈させたものを2.1.1 と同栐の処理により混合金属酸化物とした。

Table-6 $\mathrm{Fe}-\mathrm{Cu}-\mathrm{Cd}-\mathrm{O}$ catalyst.

\begin{tabular}{r|c|r|c}
\hline $\begin{array}{c}\text { Cata. } \\
\text { No. }\end{array}$ & Method & $\begin{array}{r}\text { Ratio of component* } \\
1 / 2 \mathrm{Fe}_{2} \mathrm{O}_{3}: \mathrm{CuO}: \mathrm{CdO}\end{array}$ & $\begin{array}{c}\text { Yield of mixed } \\
\text { metal oxide } \%\end{array}$ \\
\hline 8 & a & $100: 20: 20$ & 93.7 \\
8 & $\prime \prime$ & $100: 20: 200$ & 88.1 \\
10 & b & $100: 20: 20$ & 95.0 \\
11 & $\prime \prime$ & $100: 20: 50$ & 93.5 \\
\hline
\end{tabular}

* Values based on g-atom of nitrates before mixing.

$2 \cdot 3 \cdot 2$ 原 料

市販ヌカ油脂肪酸メチルを蒸留精製し，炭素数 16 お よび 18 の脂肪酸のみからなる混合脂肪酸メチルを用い た。その性状は, S.V.=196.6, I.V.=87.5, A.V.气0。

$2 \cdot 3 \cdot 3$ 還元反応

$2 \cdot 1 \cdot 3$ と同様に行なった。

$2 \cdot 3 \cdot 4$ 実験結果および考察

還元生成物のケン化価，ヨウ素価および GLPC より 求めた副生炭化水素量を Table-7 に示した。

Table-7 Hydrogenolysis of fatty ester using $\mathrm{Fe}-\mathrm{Cu}-\mathrm{Cd}-\mathrm{O}$.

\begin{tabular}{c|c|c|r|c|c}
\hline \multirow{2}{*}{ Run } & Cata. & $\begin{array}{c}\text { Reaction } \\
\text { temp. } \\
\left({ }^{\circ} \mathrm{C}\right)\end{array}$ & \multicolumn{3}{|c}{ Product } \\
\cline { 4 - 6 } & No. & S.V. & I.V. & Hydrocarbon* \\
\hline 56 & 9 & 260 & 155.7 & 75.1 & trace \\
54 & 8 & $\prime \prime$ & 13.0 & 31.0 & $"$ \\
57 & 10 & 240 & 31.9 & 58.6 & $" 1$ \\
55 & $\prime \prime$ & 260 & 3.4 & 40.0 & $<1 \%$ \\
58 & 11 & $\prime \prime$ & 60.0 & 75.0 & $<3 \%$ \\
\hline
\end{tabular}

* Estimated from GLPC

Reaction condition; Raw methyl ester : $4.0 \mathrm{~g}$, Cata. :

$0.4 \mathrm{~g}$, Reaction time : $2 \mathrm{hr}$, Initial $\mathrm{H}_{2}$ press. $: 200 \mathrm{~kg} / \mathrm{cm}^{2}$.

触媒 9 は多量のカドミウムを含むものであり, その水 素化分解に対する活性は著しく低下しており, 触媒 8 は エステルの $93 \%$ が水素化されたときにはその不飽和度 は 35\% に低下した。触媒 11 も多量のカドミウムを含 むむので, 水素化分解速度は低下しているにもかかわら ず炭化水素の生成がかなり認められ，いずれも望ましい 結果は得られなかった。触媒 10 は $240^{\circ} \mathrm{C}$ では反応は 充分進行していないが， $260^{\circ} \mathrm{C}$ で水素化分解 $98 \%$ ，不 飽和度の残存率 $41 \%$ を示し比較的良好な結果を示した が，炭化水素の生成が少量認められ，本 $\mathrm{Fe}-\mathrm{Cu}-\mathrm{Cd}-\mathrm{O}$ 系触媒による不飽和アルコールの製造は望ましい結果を 得るには至らなふった。

\section{$2 \cdot 4$ 鉄を主体とする 酸化物触媒の 水素化反応前後の} 状態について

接触還元反応において, 酸化物触媒がぞのような変化 を受けて, どのような状態のものが触媒として活性を示

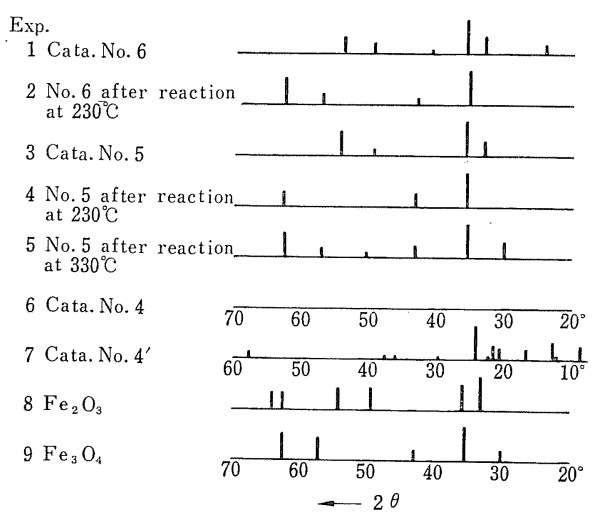

Fig.-6 X-ray diffraction diagram of metal oxide catalyst containing $\mathrm{Fe}$ oxide $\left(\mathrm{Cu}, K_{\alpha}\right.$ : $\lambda=1.5418 \AA$ ).

すものであるかは興味のある問題である。本節では被還 元原料としてパルミチン酸メチルを用い, 反応前後の触 媒の状態を粉末 X 線回折により調べた。

$2 \cdot 4 \cdot 1$ 実験結果㐨よび考察

鉄の分析には好をしくない $\mathrm{Cu}-K_{\alpha}$ を使用したため第 2 抢よび第 3 成分の回折線の得られないものが多く,

Fig.-6 exp. 6 のように第 3 成分を多く含むものではま ったく回折線の現われないものもあったが，その他のも のについては，鉄に関しては他成分の存否に関係なく明 らかにすべて $\mathrm{Fe}_{2} \mathrm{O}_{3}$ から $\mathrm{Fe}_{3} \mathrm{O}_{4}$ に還元されていること が認められた。また触媒の再使用によってもアルコール 収率梳高、值を示しており， $\mathrm{Fe}_{3} \mathrm{O}_{4}$ の形が活性を持つも のであることが推測された。

触媒をあらかじめ水素気流中 $300^{\circ} \mathrm{C}$ で還元したのち 使用した場合 Table-9 に示すように収率はかなり低下 しており，X線回折図も $\mathrm{Fe}_{3} \mathrm{O}_{4}$ 以外のものの存在を示し ている。一方 Fig.-6 exp. 5 亿示したように $330^{\circ} \mathrm{C}$ の還 元温度であっても脂肪酸エステル中での反応では $\mathrm{Fe}_{3} \mathrm{O}_{4}$

Table-8 Activity of re-used catalyst.

\begin{tabular}{c|c|c}
\hline Run & Catalyst & Alcohol yield (\%) \\
\hline 21 & No. 5 & 98 \\
22 & Re-use of No. 5* & 97 \\
\hline
\end{tabular}

* Catalyst wss what had been used in reaction No.21 and then been filtered.

Reaction condition; Raw ester : $4.0 \mathrm{~g}$, Catalyst : $0.4 \mathrm{~g}$, Reaction temp. : $220^{\circ} \mathrm{C}, \mathrm{H}_{2}$ initial press. : $200 \mathrm{~kg} / \mathrm{cm}^{2}$, Reaction time : $2 \mathrm{hr}$.

Table-9 Activity of pre-reduced catalyst.

\begin{tabular}{c|c|c}
\hline Run & Catalyst & Alcohol yield (\%) \\
\hline 4 & No.4 & 92.6 \\
31 & No.4' & 75.1 \\
\hline
\end{tabular}

Reaction condition; $;$ Raw ester $: 4.0 \mathrm{~g}$, Temp. $: 220^{\circ} \mathrm{C}$, Time : $2 \mathrm{hr}, \mathrm{H}_{2}$ initial press. : 200 $\mathrm{kg} / \mathrm{cm}^{2}$. 
の回折線のみが認められ，明らかに異なった還元状態の ものが得られ，水素気流中で予備的に還元されたものは 本還元反応の触媒として望ましくないものであった。

以上鉄系混合金属酸化物触媒 $\mathrm{Fe}_{2} \mathrm{O}_{3}$ が $\mathrm{Fe}_{3} \mathrm{O}_{4}$ まで還元され，この形が水素化分解に
対して活性を示すものであると推測された。

\section{(昭和 43 年 1 月 19 日受理)}

文献

1）池田, 服部, 小森, 油化学, 15, 12 (1966)

2) 小森, 油化学, 15, 2 (1966)

\title{
アルキルベンゼンの分枝度と生分解性
}

\author{
藤原康雄・竹園哲也・京野三郎・ \\ 阪柳定男*。山里一英*。飯塚広* \\ 日本石油株式会社中央技術研究所 (川崎市夜光 2 丁目 3 番 2 号) \\ *東京大学応用微生物研究所 (東京都文京区弥生 1 丁目 1 番 1 号)
}

\section{Effect of Alkyl Chain Branching on the Biodegradability of Alkylbenzene Sulfonates}

Yasuo Fujiwara, Tetsuya Takezono, Saburō Kyōno, Sadao Sakayanagi*, Kazuhide Yamasato* and Hiroshi IrzukA*

Central Technical Research Laboratory, Nippon Oil Co., Ltd. (2-3-2, Yakō, Kawasaki)

*Institute of Applied Microbiology, University of Tokyo (1-1-1, Yayoi, Bunkyō-ku, Tokyo)

Degree of alkyl chain branching of various commercially available detergent alkylates, including straight chain type, branched chain type and mixture thereof, was studied by means of highresolution nuclear magnetic resonance, and an explicit correlation between alkyl chain branching of detergent alkylates and biodegradability of their sulfonates was obtained.

The degree of alkyl chain branching in detergent alkylates is expressed by a parameter $\frac{\mathrm{H}_{\mathrm{CH}_{3}}-6}{\Sigma \mathrm{H}-5}$, which is obtained by a combination of NMR and gaschromatography, where $\mathrm{H}_{\mathrm{CH}_{3}}$ and $\Sigma \mathrm{H}-5$ denote the number of methyl hydrogens and the total number of hydrogens in the alkyl chain, respectively.

A plot of this parameter for the alkyl chain branching of detergent alkylates against biodegradability of their sulfonates was found to be almost linear as in Fig.-3.

Use of $\mathrm{H}_{\omega}$, which denotes the number of total methyl hydrogens in the alkyl chain, instead of $\mathrm{H}_{\mathrm{CH}}$ in the parameter leads to a lack of the linearlity of the plot of the alkyl chain branching against the biodegradability of sulfonates as in Fig. $-\mathbf{4}$. Whereas, biodegradability of alkylbenzene sulfonates can be more rapidly predicted, since $\mathrm{H}_{\omega}$ can be derived only from NMR spectra of hydrogens in the alkyl chain in detergent alkylates.

\section{1 緒言}

合成洗剤の活性分であるアルキルベンゼンスルホン酸 塩のアルキル基の構造は生分解性に影響を与え, 分枝ア ルキル基を有するものは排水後河川のアワ立ち, 下水処 理場のアワ立ちなどの公害問題に関連があるといわれて おり，わが国に掠いても生分解性合成洗成への転換が進 められている。

アルキルベンゼンスルホン酸塩の生分解度の測定方法 はすでに 1967 年 4 月より日本工業規格 (JIS) において 制定されているが，測定に通常 2 週間という長期間を要
するため，たとえばアルキルベンゼンの製造工程におけ る品質評価,管理の方法としては必ずしも適当ではない。 本報告はアルキルベンゼンスルホン酸塩の生分解性を 迅速簡易に予測することを目的として，各種市販アルキ ルベンゼンのアルキル基の構造について核磁気共鳴吸収 スペクトル (NMR) による解析を試み，アルキル基の 構造とスルホン酸塩の生分解性との関連について検討し た。

\section{2 実験}

NMR によるアルキルベンゼンのアルキル基の構造解 